Article

\title{
Trans* Politics and the Feminist Project: Revisiting the Politics of Recognition to Resolve Impasses
}

\author{
Zara Saeidzadeh * and Sofia Strid \\ Department of Gender Studies, Örebro University, 70281 Örebro, Sweden; E-Mails: zara.saeidzadeh@oru.se (Z.S.), \\ sofia.strid@oru.se (S.S.) \\ * Corresponding author
}

Submitted: 24 January 2020 | Accepted: 7 August 2020 | Published: 18 September 2020

\begin{abstract}
The debates on, in, and between feminist and trans* movements have been politically intense at best and aggressively hostile at worst. The key contestations have revolved around three issues: First, the question of who constitutes a woman; second, what constitute feminist interests; and third, how trans* politics intersects with feminist politics. Despite decades of debates and scholarship, these impasses remain unbroken. In this article, our aim is to work out a way through these impasses. We argue that all three types of contestations are deeply invested in notions of identity, and therefore dealt with in an identitarian way. This has not been constructive in resolving the antagonistic relationship between the trans* movement and feminism. We aim to disentangle the antagonism within anti-trans* feminist politics on the one hand, and trans* politics' responses to that antagonism on the other. In so doing, we argue for a politics of status-based recognition (drawing on Fraser, 2000a, 2000b) instead of identity-based recognition, highlighting individuals' specific needs in society rather than women's common interests (drawing on Jónasdóttir, 1991), and conceptualising the intersections of the trans* movement and feminism as mutually shaping rather than as trans* as additive to the feminist project (drawing on Walby, 2007, and Walby, Armstrong, and Strid, 2012). We do this by analysing the main contemporary scholarly debates on the relationship between the trans* movement and feminism within feminist and trans* politics. Unafraid of a polemic approach, our selection of material is strategic and illuminates the specific arguments put forward in the article.
\end{abstract}

\section{Keywords}

antagonism; coalitional intersectionality; feminist politics; identity; misrecognition; status; trans* politics

Issue

This article is part of the issue "Trans* Politics: Current Challenges and Contestations" edited by Mieke Verloo (Radboud University, The Netherlands) and Anna van der Vleuten (Radboud University, The Netherlands).

(C) 2020 by the authors; licensee Cogitatio (Lisbon, Portugal). This article is licensed under a Creative Commons Attribution 4.0 International License (CC BY).

\section{Introduction}

The debates on the antagonism against trans* issues within the feminist movements have been politically intense at best and aggressively hostile at worst. Key contestations have revolved around what it means to be a woman, what feminist interests really are, and how trans* politics intersects with feminist politics. These debates are not new, but have recently received renewed attention. The past decades of debates and scholarship have proposed ways forward and different solutions to these impasses. These have been met with various degrees of antagonism, in particular from the realm of rightwing and conservative politics, but also from women's movements within the larger feminist project. This hostility within the feminist project in contemporary debates concerning trans* issues is to some extent unsurprising: When marginalised groups break their silence and demand inclusion in established politics or social movements, they are rarely embraced by the majority. Instead, they often meet opposition and accusations of fragmenting the wider movement, focusing on details and trivial 
issues, and polarising the cause-whatever that cause might be. Some semi-contemporary examples include the demands and voices of women in the workers' rights movement, of Black and ethnic-minority feminists in the white feminist movement, and of trans* women in feminism. When previously silenced groups speak (out), the majority group is challenged to rethink its basis, ideology, inclusion, privilege, and politics of representation, a process that may be both challenging and agonising (Lépinard \& Evans, 2019).

Debates and practices among radical feminists and other scholars and activists continue to challenge whether trans* women are women, thus attempting to exclude trans women from feminist alliances and the overall feminist project. Trans Exclusionary Radical Feminists (so-called TERFS) and some gender-critical feminists within radical feminism have actively opposed trans* politics. Trans* activists and scholars criticise such 'transphobic' feminists for misusing their privilege to monopolise the category of women. An example is Sheila Jeffreys's book Gender Hurts: A feminist Analysis of the Politics of Transgenderism, where she writes trans* people are an assault on feminism, women, and children. Jeffreys is an established Australian feminist scholar, well-known for her critiques of queer theory, sex work, and pornography.

We use the term trans* with asterisk to denote that trans* indicates a special relation and trans* embodiments in order to avoid an identarian conceptualization of trans* (Rees, 2016, p. 230). We do not understand trans* as only in relation to gender categories assigned to men and women (Stryker, Currah, \& Moore, 2008, p. 12). Therefore, we apply the asterisk to trans* to give conceptual bearings on specification and speciation; trans* is "more than and equal to one" (Hayward \& Weinstein, 2015, p. 196).

In this article, we investigate the anti-trans* movement within the feminist project. The aim is to explore the roots and basis of this antagonism in order to examine if and how an alternative understanding may contribute to overcoming an antagonism that we think is rooted in identity-based (mis)recognition. Instead, we explore and suggest recognition based on the status and needs shared by both trans* politics and the feminist project. We use the concept 'feminist project,' inspired by the work of Walby (2011; see also Verloo, 2018), to include all activities, practices, programs within groups, and organisations that share feminist goals. With this definition, Walby (2011) widens the concept of a social movement by including a wider set of ideas, actors, and practices as long as they have the general objective of societal change, and as long as its actors and activities are attempting to achieve that change. Such movements are inherently dynamic but they are united by their general direction: For the feminist project, that direction is against gender inequality and toward improving the position of women, but for the elements within that project their specific focus, content, and strategy can and does differ and change across time and space.
In our analysis of the shared history of trans* politics and feminism in civil society, we see them both as constitutive parts of the feminist project. We identify a critical turning point in the structure of global movements coinciding with a shift away from activism around rights and interests, and towards identity. But neither the split nor the hostility has always existed. It is a recent antagonism based on specific notions and analyses of who constitutes a woman and who has the right to make claims as a woman within the feminist project (Hines, 2017; Moghadam, 1994). This raises epistemological questions of who can write on what: Can only women write about the experiences of women? And if so, which women? Can only trans* people write about trans* people, and can only lesbian people write about lesbian people? Writing from a perspective that you do not embody but embrace constitutes situated, not embodied knowledge, and must be done carefully-but it can be done. Taking this position means carefully acknowledging one's situatedness and politics of location (Haraway, 1988).

By tracing the pre identity-based history of the role of trans* politics within the feminist project and their coalitions and alliances, we argue that the issue of who constitutes a woman as the key contestation is based on false, or at least unfortunate, premises, drawing on the investments of both anti-trans* feminist and trans* theories and practices of identity-based recognition. Putting the spotlight on the contemporary and particularly hostile debates makes the underlying problems relatively easy to identify. But the solution does not lie in group politics with a broader base, or a politics of (organised) interests (see e.g., Jónasdóttir, 1991; Jones \& Jónasdóttir, 1988), but rather in embracing a politics of (mis)recognition based on status and needs (Fraser, 2000a, 2001; see also interview with Fraser in Dahl, Stoltz, \& Willig, 2004). We perceive identity-based politics of recognition versus status-based that is the Hegelian understanding of recognition that emphasises on identity and that identity is constituted in relation to recognition by others. Therefore, misrecognition means devalued identity by the dominant culture which places recognition in individual subjectivity (Honneth, 1995). However, statusbased recognition, according to Nancy Fraser (2000a, pp. 24-27) is to treat recognition as a social status which does not mean devaluing group identity; it means social subordination in a sense that prevents people from parity participation in social life. That is why status-based recognition focuses on the needs of people to be able to participate in social life. Moreover, as Fraser (2000a, p. 27) explains, perceiving recognition as status "places the wrong in institutionalized social relations, not in individual or interpersonal psychology."

\section{Shared History}

Trans* activists have always worked in alliance and coalition with other social movements, including the feminist project. In this section, we shed light on this shared 
history of the feminist project and trans* politics, drawing on literature in English. We conceptualise this shared history as a status-and-needs-based alliance between trans* and feminism; the section notes how trans* activists worked in alliance and coalition with other social movements, including feminist ones, around shared oppressions, e.g., gender-based legal, political, medical, and social oppression (Stryker, 2017, p. 96). There have been joint struggles, including surveillance and police harassment, exclusion from social services, discrimination in housing and employment opportunities, and the lack of legal status. Even though there are narratives of longheld tensions between sections of the feminist project and trans* activism, there are concurrent histories of solidarity and alliance. Many of the early radical feminist movements were not hostile towards trans* women (Hines, 2017; Stryker, 2004, 2008, 2017; Williams, 2014).

Trans* activism is intertwined with the history of early 20th century gay emancipation in Europe and the US. In Europe, it dates back to as early as 1910, when German physician and sexologist Magnus Hirschfeld advocated for homosexual rights and later transsexual rights. These alliances were ongoing until the 1930s, when the rise of fascism and the rule of Nazism in Europe did not allow for much activism. In fact, in 1933, the Hitler regime burnt down Hirschfeld's Institute for Sexual Science in Berlin.

Drawing on coalitions and the shared history of feminist and trans* activism, Stryker (2008, 2017), Professor of Gender and Women's Studies and founder of the Transgender Studies Initiative at the University of Arizona, emphasises the historical existence of the US' trans* liberation movement, starting around the 1850s, and joining the feminist and gay-liberation movements from the 1950s until the early 1970s. Early on, trans* activism in the US was formed through individual actions. Stryker (2017) maps out the events in cafes and restaurants in different cities (e.g., the unrests at LA's Cooper D-Nut in 1959, Philadelphia's Dewy in in 1969, San Francisco's Compton cafeteria in 1966, and New York City's Stonewall Inn in 1969) that paved the way for the contemporary trans* movement for social change, yet are usually misunderstood as stemming from the gay-liberation movement alone.

The touchstone of intersectional feminist movements that addressed trans* issues, according to Stryker (2017), was Black feminists' 1973 founding of the National Black Feminist Organisation (including activists from the civil-rights movement, the Black Panthers, and the Black Lesbian Caucus of the Gay Liberation Front) which was an important early site for feminist politics in coalition with trans* activists. Thus, inspired by their activism, the Combahee River Collective criticised all biological determinism a year later, calling it "a dangerous and reactionary basis upon which to build a politic" (Stryker, 2017, p. 124). Trans* politics and feminism may share different theoretical stands, but their history and activism are weaved together (Scott-Dixon,
2006). The relationship between feminist theory/politics and trans* theory/politics has been interactive as well as intersectional, but historically and politically distinct (Bettcher, 2017). Feminist intersectional analyses accounted for trans* people's experience in the early 1980s that is argued to have laid the foundation for trans* feminism (Stryker \& Bettcher, 2016).

In the US, the early 1970s marked a turning point in the shared history of trans* politics, gay liberation, and the feminist project (Stryker, 2017). Key here was a fissure in the coalitional structure between feminist and trans* politics. Three separate underpinning issues and events relating to law, activism, and academia can be identified as causes of this watershed moment, leading to legal, activist, and academic divergence between feminist and trans* politics. We argue that the legal divergence between the trans* community on the one hand and feminist and gay communities on the other happened because of some feminist lesbian and gay activists' opposition against the medical and legal systems which clashed with trans* people negotiating their medical transition with the state. Another reason was the depathologisation of homosexuality in the Diagnostic and Statistical Manual of Mental Disorder (DSM) in 1973 and the pathologisation of trans* identification as a psychological disorder in the 1980s. The activist divergence, meanwhile, occurred in the late 1990s, when feminists excluded trans* women from the Michigan Womyn's Music Festival on the basis of so-called 'womyn-bornwomyn' politics, which caused a huge breakdown between trans* women and feminist activists. It created a hallmark division in women, queer, and trans* political discussions and led to the creation of a parallel festival called Camp Trans. The academic divergence took place around scholarly debates on the 'gender authenticity' of women focusing on women's bodies and their experience of womanhood, particularly in the writings of some UK and US based feminist academics (cf. Daly, 1978; Jeffreys, 1997, 2014; Raymond, 1979). Based on biologically deterministic politics, they argued that transsexuality [sic] involved those primarily unhappy with strict gender roles; transsexuals [sic] were labelled "gender conservatives" with "false consciousness" about their assigned genders (Elliot, 2010, p. 56).

In response to the hostility of some feminists towards trans* people and activism, trans*-sympathetic scholars have developed theories and practices to ensure trans* politics are part of feminist politics in the Western world. The early, central text in this regard is Stone's (1987/1992) The Empire Strikes Back: Posttranssexual Manifesto, a response to Raymond's (1979) highly contested and widely criticised book, The Transsexual Empire: The making of She-Male. As a result, a flux of publications in English (i.e., Devor, 1997; Ekins \& King, 2001; Prosser, 1998; Stone, 1987/1992) have argued the case for trans* knowledge and experience since the late 1980s. 


\section{Investigating the Debates: Problems and Solutions}

There is a growing line of literature addressing the vexed relationship between anti-trans* feminists and trans* politics, identifying different causes and proposing different solutions to end the standoffs. We note that the English-language literature on this topic tackles: 1) the debates about the struggle for justice through identitybased recognition; 2) the debates on identity-based group interests, which focus on either women's or trans* interests; and 3) the debates on a particular intersectionality concentrated on either including or excluding trans* people and issues from feminist politics. In this section, we discuss how these three key debates are shaped around issues of who is a woman, whose interests are at stake, and who is included or excluded in feminist politics (and why).

Scholars (cf. Bettcher, 2017; Elliot, 2004; Hines, 2017) have addressed that the main site of the contestation raised by anti-trans* feminist politics is about the question of who constitutes a woman: Are trans* women women? This question is based on the idea that only specific time-bound bodily experiences qualify certain bodies as women's bodies. This, we conceptualise as an identity problem. The literature that address this contestation suggest different ways to resolve the antagonism between anti-trans* feminists and trans* politics. Elliot (2004), for example, suggests that, since social and political lives cannot be addressed without knowing the identity of the person, feminism should battle all oppression and problematise identity instead of politicising it. For Elliot (2004), dismissing cultural meanings of transgender identities is not helpful to a feminist project combating oppression, both because trans* activists raise questions regarding sex, gender, and embodiment that are important to non-trans* feminists, and because resisting feminists who promote public awareness about trans* issues might undermine their work of awareness raising and opposition to transphobia. Hines (2017) criticises the focus on identity, and frames the question of who constitutes a woman as an issue centred on a woman's body, not her identity. Hines (2014, p. 85) suggests valuing "subjectively located bodies" instead of women's experiences of their female body. Taking the argument further, Bettcher (2017, pp. 4-5) suggests there should be multiple meanings of 'woman' instead of one narrow category; oppression is "the invalidation of trans* identities that arises from organised gender practices" in society. Further, Bettcher (2017) argues that feminist philosophers' narrow focus on the question of trans* women overlooks the reality of trans* people, which involves more issues than gender identity. Since these debates all revolve around identity, arguing either for or against, it becomes tricky to resolve the contestations without first resolving the question of identity.

Another main site of antagonism revolves around who is the concern of the feminist project. In other words, are trans* women's interests feminist interests?
We can see how identity-based interests, such as those of trans* women, have led to discussions on including some people and excluding others from the feminist project. To solve this problem, Serano (2013) suggests feminism should pay more attention to sexism and the marginalisation of trans* people instead of engaging in Oppression Olympics. Oppression Olympics, coined by feminist activist Elizabeth Martínez in 1998, is the characterisation of exclusion or marginalisation as a competition between individuals or groups, often based on gender, race, ethnicity, socioeconomic status, sexuality, or other inequality grounds (Martínez, 1998). Whoever is the most excluded or marginalised-worst off-'wins' these Olympics. Whoever is more authentic, more oppressed, is more 'correct' (Dhamoon, 2011; Shannon, Rogue, Daring, \& Volcano, 2013). Serano (2013) problematises the notions that cisgender women are more oppressed than trans* women and that trans* women have a history of male privilege. For her, it is reductive to ask whether trans* women's interests are the interests of the feminist project. Instead, she suggests that fighting any form of sexism and marginalisation is in the interests of feminism, and that, since trans* people are affected by institutionalised cissexism and trans-misogyny, their interest is at stake in the feminist project. Feminist scholars such as Yuval-Davis (2010) and Hancock (2011) have both suggested various forms of intersectionality theory as a route out of the antagonist debate between anti-trans* feminist and trans* politics.

Since the 1970s, trans* activists and scholars in English language literature have argued for including trans* issues into feminist politics and against trans*exclusionary feminism. However, the inclusion of trans* issues into the feminist project is faced with limitations (Johnson, 2015). Let us give two examples from two non-English speaking contexts: Québec and Iran. In Francophone Canada, the feminist fixation around women's interests and lack of theorising and discussing trans* issues, according to Baril (2016), is explained by how 1970s Francophone feminism did not consider trans* issues worth a political battle for social change. Some recent developments have simply added trans* issues to policies, theories, and practices-as if addition is inclusion. Though, it remains necessary to investigate deeply the theory behind the silence and the dichotomy of inclusion and exclusion in order for the Francophone voices of trans* feminism to emerge in Canada. The second example comes from the Iranian context, where feminist groups do not include trans* issues into their agendas (Peyghambarzadeh, 2019) because the dominant feminist discourse in Iran is based on cisgender and heterosexuality, both of which exclude perceptions of other genders or sexualities. Moreover, the feminist project in Iran self-censors its activism because of the social and political strains it is under. For example, feminist politics in Iran maintain a rationale of not being able to afford to advocate for the rights of gay people (Peyghambarzadeh, 2019). Iranian feminists outside Iran 
even condemn or abstain from discussing trans* politics, claiming it does not fit their political interests and like the 1970s US and UK based anti-trans* feminists, they argue that body modification through surgery for the purpose of changing one's sex is a patriarchal force and a harmful cultural practice (cf. Amin, 2016; Rahbari, 2016). Simply adding trans* into feminist politics would not resolve the antagonism among anti-trans* feminists and trans*politics. The idea of 'merely adding', to which Namaste $(2009$, p. 20) draws our attention, has been resisted by feminist theory for a long time on the question of who is a woman "by resisting mere insertion to existing theories, feminists have been writing against 'add women and stir' approach."

In English language literature, a new scholarship has developed within trans* studies to explicitly address the intersection of trans* and feminist politics. US trans* activist Emi Komoya popularized transfeminism [sic] through her Transfeminist Manifesto published on her website in 2001 and based it on individual rights to body and expression of identity. Trans* feminism emerged as a result of trans* politics' endeavour for 'inclusion' of trans* issues in feminist politics in the West. Such a trans* feminist perspective is a way to bring transgender people from the margin to the centre of women's and gender studies (Enke, 2012; Serano, 2013).

As of the mid-1990s, scholarly journals devoted special issues to the feminist and trans* politics, for example Trans* Sister: A journal of Transsexual Feminism (1993-1995), Rites of Passage (1991-1992), GLQ: A Journal of Lesbian and Gay Studies, Sexualities (1998) and Velvet Light-Trap (1998) in the US, Gender Trash (1992-1995) in Montreal, Journal of Gender Studies' special issue (1998) in the UK (Stryker \& Bettcher, 2016). Hypatia: A Journal of Feminist Philosophy published a special issue on Transgender Studies and Feminism: Theory, Politics and Gendered Realities (2009, Vol. 24, Issue 3) that focused on the intersection of trans* issues and feminism. In their introduction, Bettcher and Garry (2009) wrote that the dialogue between trans* politics and feminism is dangerous; both emphasise gender too much and risk marginalising other forms of oppression. Instead, Bettcher and Garry (2009) suggested a broader dialogue that includes more aspects of racism, sexism, and colonialism. Enke (2012) defines trans* politics as trifold, acknowledging that: 1 ) binary gender norms and gender hierarchies are maintained through violence against those who deviate; 2 ) there are people who do not conform to conventional gender roles; and 3) gender variation is essential for creation of a wellfunctioning society. All three, we argue, undergird the idea of gender transgression in trans* politics, which limits the politics of recognition to merely gender identity and the transgression of gender norms. In such a politics, a trans* woman who is subjected to violence because of her job as a sex worker or her socio-economic position, rather than her trans* identity, would not be protected (cf. Namaste, 2000, 2005).
In all these proposed ways out of antagonism, we argue, the struggles are seen as part of a politics of recognition based on identity. This leads us to question an identity-based politics of recognition as it is practiced in both anti-trans* feminist and trans* politics. Hines (2013) adopts the same position, explaining that identity has operated as an excluding mechanism, but she calls for a politics of difference. We, however, believe that a politics of difference is not enough to address inequality and misdistribution (Lovell, 2007). According to status-based recognition, social and political injustices do not merely rest on different patterns of cultural representation, and focusing on identity alone tends to ignore the social, political, and economic structures undergirding injustice. Halberstam (2018, p. 127) also criticises contemporary trans* theory for being invested in identitarian conflicts that turns on small difference and individual hurts and instead suggests trans* and feminist activists should work together to oppose the violent imposition of "economic disparity and white supremacy in the United States." Explaining that the conflict between some second-wave feminists [sic] and trans* women has blocked coalition building in the US, Halberstam (2018, p. 128) calls for a "global trans*feminism," that is not only for trans* women but all women.

Furthermore, we would like to problematise both trans* politics and anti-trans* feminist politics that focus only on the interests of certain categories of people, which we think does not serve the purpose of either feminist or trans* politics. Moreover, recognition based on group interests pushes trans* people to the margin and forces them to identify under certain categories. We believe the dichotomy of exclusionary anti-trans* feminism and inclusionary trans*-affirming feminism limits the scope of the feminist project into limited identitarian categories and thus fails to understand the intersectional nature of trans* and feminist politics, not to mention the fact that feminism and feminist interests are not universal. The long historical account of coalitions and collaboration between trans* and feminist politics shows that the inequality grounds for both were mutually shaped, and that feminist politics clearly intersects with trans* politics.

Problematising the gender knowledge based on women's bodies and experiences, we think it is necessary that trans* people are recognised as equal members of society. Moreover, problematising the binary between trans*-inclusionary and-exclusionary feminism, we think it is important to acknowledge the historical intersectionality of the two, as one of many steps to reconcile feminist and trans* politics. To borrow a concept from intersectionality politics, we conceptualise the two as mutually shaping and constitutive forms of politics (Walby, Armstrong, \& Strid, 2012).

\section{Alternative Politics}

In this section, we propose an alternative politics to break out of the impasses between anti-trans* feminists 
and trans* politics outlined above. This would work by: 1) revisiting a politics of recognition based on status; 2) understanding interests as a matter of individual and group-based needs in society; and 3) using the concepts of political and coalitional intersectionality as mutually shaping inequalities, instead of including trans* issues to the feminist project.

\subsection{Status-Based (Mis)Recognition}

Above, we identified several identity-based struggles for recognition within feminist and trans* politics: the antitrans* feminist activists' biologically deterministic understanding of women and their focus on women as an identity category, and on the other hand trans* activists' focus on individual trans* identity subjectivity.

Inspired by the work of Fraser (2013), who maintains that recognition should be treated as a question of social status, not group-specific identity, we propose that feminists need to rethink the questions of who constitutes a woman, whose interests are at stake, and who would be included in the feminist project if we assumed a politics of recognition based on status rather than identity. Fraser (2000b) explains how identity-based politics encourages separatism and sometimes antagonism, so we propose instead a status-based recognition of trans* people within feminist politics-that is, recognising trans* people and their needs as equal members of society, a necessary move to ensure justice and attain equal distribution and political representation. Fraser (1997, p. 280) states: "Misrecognition is an institutional social relation not a psychological state." Therefore, she proposes, the aim should be to de-institutionalise subordinating social patterns that make some group of people normative and another deficient. Since misrecognition happens when institutionalised values deny people's parity participation in society, to remedy misrecognition, people's social status in society should be recognised, not their marginalised identities.

Fraser (2000a) suggests that institutionalised misrecognition takes the shape of legislation, governmental policies, and professional practices that constitute some categories of people as inferior members of society. For Fraser (2001), social change is difficult to envisage through identity-based recognition, not to say impossible: Viewing misrecognition as damaged identity means emphasising the psychological and individual over social institutions and interactions. Following Fraser (2013), we see the feminist misrecognition of trans* people as the result of institutionalised relations of social subordination towards trans* people, and not the idiosyncratic and identitarian values of a few old-fashioned feminists. We argue, the antagonism must be tackled by deinstitutionalising the subordination of trans* people in society. This requires understanding gender as status, not just identity, focusing on people's needs instead of identitygroup interests, and allowing the political representation of trans* and feminist politics to be mutually constituted.

\subsection{Needs-Based Interest}

The idea that political concerns could be conceptualised in terms of different groups' common interests has been rejected by feminist scholars on at least two different grounds: by rejecting the concept of either interests or groups. In the first case, interest theory as such was seen as inappropriate for women's concerns and political struggles. Diamond and Hartsock (1981, p. 719) rejected the very language of interests as inapt to understand political life since it fails "to assign priorities to human wants, needs, objectives, and purpose, and in so doing implicitly supports the right of the strong to prevail in every contest." The arguments to reject the concept of groups is based on people's diversity (Pringle \& Watson, 1992). Judith Butler (1990, p. 1) argues that, since women are so diverse, we can no longer define them as a group, and that the "very subject of women is no longer understood in stable or abiding terms." The post-structuralist argument is that to think of groups, women, or others as having interests in common is essentialist and totalising. Group thinking is felt to impose common concerns on a necessarily heterogeneous divided category of women (Pringle \& Watson, 1992). However, far from everyone rejects these two concepts. A basic-level approach includes understanding and analysing interests as empirical generalisations about individual ideas or preferences on specific political issues; that is, interests are conceptualised as subjectively held attitudes (Jónasdóttir, 1991, p. 160). Social and political interests are no more or less than an articulation of individual preferences on specific issues in specific contexts where common interests may exist as empirically verifiable generalisations. Political scientist and gender studies scholar Anna Jónasdóttir (1991) does not abandon the concept of interests and replaces it with a theory of needs, nor does she trace the commonality of women's interests to solely or mainly the reproductive division of labour (Sapiro, 1981). It is rather to "transcend the either/or situation that the Diamond and Hartsock versus Sapiro debate suggests" (Jónasdóttir, 1991, p. 152). Thus re-defined, the concept of interests is useful and "particularly significant in analysis of the society we actually live in" (Jónasdóttir, 1991, p. 152; see also pp. 157-159, 164-170).

By understanding political coalitions or alliances between trans* and feminist politic, as based on needs and common interests rather than identities, we can move towards a politics that requires recognising people's status in society. These common needs and interests can be located in: 1) not being oppressed as a woman or a trans* woman (Jónasdóttir, 1991), but as members of society with shared experiences of oppression; 2) avoiding marginalisation and exclusion as women and trans* women; and 3) understanding feminist and trans* feminist points of political departure as distinct yet with the same goals (Bettcher \& Garry, 2009). Thus, a broader approach is necessary rather than just focusing on the intersections of sexism and transphobia. 
We disagree with rejecting the concept of interests and argue that needs-based rather than identity-based interests may be useful to talk about common concerns to avoid homogenising (gendered) groups of people. The debate is taken further by arguing for status-based recognition using the notion of needs and interests instead of identity. A shared interest lies in the struggle for formal presence and the right to a controlling presence in decision-making institutions, not merely a presence (Jónasdóttir, 1991). Expressed differently, common group interests exist on the basis of not being oppressed as that group; where people are being oppressed as women in the society in which they live, there is a common interest in ending that oppression.

\subsection{Political and Coalitional Intersectionality}

Intersectionality in Crenshaw's (1991) definition can be structural or political. Structural intersectionality refers to inequalities and their intersections as directly relevant to people's experiences in society. Political intersectionality, on the other hand, refers to inequalities and their intersections as relevant to political strategies, and can be used to analyse how strategies on one inequality axis are not, or rarely, neutral towards other inequality axes. Strategies on the LGBT-axis may not be 'neutral' towards strategies on the gender axis. In fact, these may even be (perceived to be) in conflict. By simultaneously paying attention to strategies for coalition building between social justice projects and between inequalities within the social justice project, political intersectionality can be useful to analyse both coalitional intersectionality and intersectionality as a repertoire for inclusivity (Lépinard \& Evans, 2019), meaning that intersectionality can go beyond identity politics, and be both inclusive and based on coalition of interests. As such, this approach could be useful to analyse antagonism and both the absence and presence of a politics of inclusion and exclusion. Thus, we propose a perception of intersectionality that values the very political and coalitional strategies between trans* and feminist theories and practices that have always existed.

\section{Conclusions}

We have explained why the 1970 s is known as a watershed moment in the history of feminist and trans* activism in the West by showing how the vexed relationship between feminists and trans* politics led to divergences. These include: 1 ) the divergence between trans*, feminist, and gay and lesbian activism as a result of the legal and medical transitions of trans* people; 2) legal divergence due to the fact that homosexuality was declassified by DSM and trans* identification was not; and 3 ) the academic divergence between trans* and feminist scholars on gender authenticity or the question of who constitutes a woman.

The antagonistic debates and polarising practices among (some) feminist and (some) trans* activists and scholars have long resulted in a deadlock. By disentangling the current debates, we have identified three underlying problems: identity-based (mis)recognition; universal and specific group interests of feminism and trans* politics; and inclusionary intersectionality.

We have argued for the following alternatives to move beyond these impasses: 1 ) revisiting a politics of recognition based on status rather than identity; 2 ) understanding interests as a matter of individual and groupbased needs in society; and 3) introducing political and coalitional intersectionality and the concept of mutually shaping inequalities to disentangle the antagonism. Concretely, this means understanding and recognising trans* as a social status rather than just as an individual identity in need of recognition by others. By recognising the social status of trans* people in society, we allow for trans* parity participation in social life, which can lead to an equal distribution of wealth and equal political representation of trans* people in feminist politics.

\section{Acknowledgments}

We would like to express our immense gratitude to Mieke Verloo and Anna van der Vleuten, the editors of the thematic issue for their very generous support. We are also thankful for the opportunity we were given to present this article at the ECPG Conference in Amsterdam in 2019.

\section{Conflict of Interests}

The authors declare no conflict of interests.

\section{References}

Amin, S. (2016). Jinsiyat X: Tajrobeh zisti hamjinsgarayan va transgenderha dar Iran [Gender X: A glance at the situation of transgender and homosexual people in Iran]. London and Berlin: Justice for Iran and 6Rang Organizations.

Baril, A. (2016). Francophone trans/feminism's absence, silence, emergence. Transgender Studies Quarterly, 3(1/2), 40-47.

Bettcher, T. M. (2017). Trans feminism: Recent philosophical developments. Philosophy Compass, 12(11), 124-138.

Bettcher, T. M., \& Garry, A. (2009). Transgender studies and feminism: Theory, politics, and gender realities. Hypatia: A Journal of Feminist Philosophy, 24(3), 1-10.

Butler, J. (1990). Gender trouble: Feminism and the subversion of identity. London and New York, NY: Routledge.

Crenshaw, K. (1991). Mapping the margins: Intersectionality, identity politics, and violence against women of color. Stanford Law Review, 43(6), 1241-1299.

Dahl, H. M., Stoltz, P., \& Willig, R. (2004). Recognition, redistribution and representation in capitalist global 
society: An interview with Nancy Fraser. Acta Sociologica, 47(4), 374-382.

Daly, M. (1978). Gyn/ecology: The metaethics of radical feminism. Boston, MA: Beacon Press.

Devor, A. (1997). More than manly women: How femaleto-male transsexuals reject lesbian identities. In B. Bullough, V. Bullough, \& J. Elias (Eds.), Gender blending (pp. 87-102). Amherst, NY: Prometheus.

Dhamoon, R. K. (2011). Considerations on mainstreaming intersectionality. Political Research Quarterly, 64(1), 230-243.

Diamond, I., \& Hartsock, N. (1981). Beyond interests in politics: A comment on Virginia Sapiro's 'When are interests interesting? The problem of political representation of women.' American Political Science Review, 75(3), 717-723.

Ekins, R., \& King, D. (2001). Tales of the unexpected: Exploring transgender diversity through personal narrative. In F. Haynes \& T. McKenna (Eds.), Unseen genders: Beyond the binaries (pp. 19-28). New York, NY: Peter Lang.

Elliot, P. (2004). Who gets to be a woman?: Feminist politics and the question of trans-inclusion. Atlantis: Critical Studies in Gender, Culture \& Social Justice, 29(1), 13-20.

Elliot, P. (2010). Debates in transgender, queer, and feminist theory: Contested sites. Farnham: Ashgate.

Enke, F. (2012). The education of little cis: Cisgender and the discipline of opposing bodies. In A. Enke (Ed.), Transfeminist perspectives in and beyond transgender and gender studies (pp. 60-77). Philadelphia, PA: Temple University Press.

Fraser, N. (1997). Justice interrupts: Critical reflection on the "postsocialist" condition. New York, NY: Routledge.

Fraser, N. (2000a). Why overcoming prejudice is not enough: A rejoinder to Richard Rorty. Critical Horizons, 1(1), 21-28.

Fraser, N. (2000b). Rethinking recognition. New Left Review, 3, 107-120.

Fraser, N. (2001). Recognition without ethics? Theory, Culture \& Society, 18(2/3), 21-42.

Fraser, N. (2013). Fortunes of feminism: From statemanaged capitalism to neoliberal crisis. London and New York, NY: Verso Books.

Halberstam, J. (2018). Trans*: A quick and quirky account of gender variability. Oakland, CA: University of California Press.

Hancock, A. M. (2011). Solidarity politics for millennials: A guide to ending the oppression Olympics. Cham: Springer.

Haraway, D. (1988). Situated knowledges. The science question in feminism and the privilege of the partial perspective. Feminist Studies, 14(3), 575-599.

Hayward, E., \& Weinstein, J. (2015). Introduction: Tranimalities in the age of trans* life. Transgender Studies Quarterly, 2(2), 195-208.

Hines, S. (2013). Gender diversity, recognition and citi- zenship: Towards a politics of difference. London and New York, NY: Palgrave.

Hines, S. (2014). Feminism. Transgender Studies Quarterly, 1(1/2), 84-86.

Hines, S. (2017). The feminist frontier: On trans and feminism. Journal of Gender Studies, 28(2), 145-157.

Honneth, A. (1995). The struggle for recognition: The moral grammar of social conflicts (J. Anderson, Trans.). Cambridge: Polity Press.

Jeffreys, S. (1997). Transgender activism: A lesbian feminist perspective. Journal of Lesbian Studies, 1(3/4), 55-74.

Jeffreys, S. (2014). Gender hurts: A feminist analysis of the politics of transgenderism. London: Routledge.

Johnson, A. H. (2015). Beyond inclusion: Thinking toward a transfeminist methodology. In V. Demos \& M. T. Segal (Eds.), At the center: Feminism, social science and knowledge (pp. 21-41). Bingley: Emerald.

Jónasdóttir, A. G. (1991). Love power and political interests. Örebro: Örebro University.

Jones, K. B., \& Jónasdóttir, A. G. (1988). The political interests of gender: Developing theory and research with a feminist face. London: Sage.

Lépinard, E., \& Evans, E. (Eds). (2019). Intersectionality in feminist and queer movements. London and New York, NY: Routledge.

Lovell, T. (Ed.). (2007). Misrecognition, social inequality and social justice: Nancy Fraser and Pierre Bourdieu. Abingdon and New York, NY: Routledge.

Martínez, E. (1998). De colores means all of us: Latina views for a multi-colored century. London: Verso.

Moghadam, V. (1994). Gender and national identity. London and New York: Palgrave.

Namaste, V. (2000). Invisible lives: The erasure of transsexual and transgendered people. Chicago, IL: University of Chicago Press.

Namaste, V. (2005). Sex change, social change: Reflections on identity, institutions, and imperialism. Toronto: Women's Press.

Namaste, V. (2009). Undoing theory: The "transgender question" and the epistemic violence of Anglo-American feminist theory. Hypatia: A Journal of Feminist Philosophy, 24(3), 11-32.

Peyghambarzadeh, Z. (2019). Baresi jonbishi feministi va jonbishi digarbashan Iran [Examining the relations between feminist and queer movement in Iran]. Azadi Andishe, 1(7), 251-268.

Pringle, R., \& Watson, S. (1992). Women's interests and the post-structuralist state. In M. Barrett \& A. Phillips (Eds.), Destabilizing theory: Contemporary feminist debates (pp. 55-73). Cambridge: Polity Press.

Prosser, J. (1998). Second skins: The body narratives of transsexuality. New York, NY: Columbia University Press.

Rahbari, L. (2016). Transgender in Iran: Gender politics, space and harmful cultural practices. Paper presented at Trans* formation Conference: Lives and Politics beyond the Gender Binary, Lisbon, Portugal. 
Raymond, J. G. (1979). The transsexual empire: The making of the she-male. Boston, MA: Beacon Press.

Reese, S. (2016). Trans* feminist intersections. Transgender Studies Quarterly, 3(1/2), 228-234.

Sapiro, V. (1981). When are interests interesting? The problem of political representation. American Political Science Review, 75, 701-716.

Scott-Dixon, K. (Ed.). (2006). Trans/forming feminisms: Transfeminist voices speak out. Toronto: Canadian Scholars' Press.

Serano, J. (2013). Excluded: Making feminist and queer movements more inclusive. Seattle, WA: Seal Press.

Shannon, D., Rogue, J., Daring, C. B., \& Volcano, A. (2013). Queering anarchism: Addressing and undressing power and desire. Oakland, CA: AK Press.

Stone, S. (1992). The "empire" strikes back: A posttranssexual manifesto. Austin, TX: University of Texas. (Original work published 1987)

Stryker, S. (2004). Transgender activism. Glbtq. Retrieved from http://www.glbtqarchive.com

Stryker, S. (2008). Transgender history, homonormativity, and disciplinarity. Radical History Review, 2008(100), 145-157.

Stryker, S. (2017). Transgender history: The roots of today's revolution. Seattle, WA: Seal Press.

Stryker, S., \& Bettcher, T. M. (2016). Introduction:
Trans/feminisms. Transgender Studies Quarterly, 3(1/2), 5-14.

Stryker, S., Currah, P., \& Moore, L. J. (2008). Introduction: Trans*-, trans, or transgender? Women's Studies Quarterly, 36(3/4), 11-22.

Verloo, M. (2018). Understanding the dynamics of opposition to gender equality change: Lessons from and for social complexity theory. In M. Verloo (Ed)., Varieties of opposition to gender equality in Europe (pp. 38-55). London and New York, NY: Routledge.

Walby, S. (2007). Complexity theory, systems theory, and multiple intersecting social inequalities. Philosophy of the Social Sciences, 37(4), 449-470.

Walby, S. (2011). The future of feminism. Bristol: Policy Press.

Walby, S., Armstrong, J., \& Strid, S. (2012). Intersectionality: Multiple inequalities in social theory. Sociology, 46(2), 224-240.

Williams, C. (2014). TERF hate and Sandy Stone. The Transadvocate. Retrieved from http://www. transadvocate.com/terf-violence-and-sandy-stone_ n_14360.htm

Yuval-Davis, N. (2010). Theorizing identity: Beyond the 'self' and 'other' dichotomy. Patterns of Prejudice, 44(3), 261-280.

\section{About the Authors}
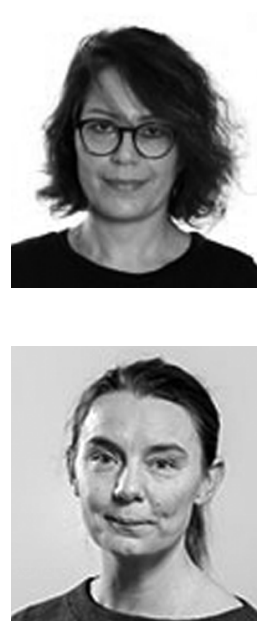

Zara Saeidzadeh is a Lecturer in Gender Studies, Örebro University, Sweden, and a Research Associate at the Simone de Beauvoir Institute, Concordia University, Canada. Her work concentrates on trans and social justice from a socio-legal perspective. Among her publications are Trans and Sex Change in Contemporary Iran (PhD Thesis, Örebro University, 2020) and "'Are Trans Men the Manliest of Men'? Gender Practices, Trans Masculinity and Mardānegī in Contemporary Iran" (Journal of Gender Studies, 2019).

Sofia Strid is Associate Professor in Gender Studies, Örebro University, Sweden. She has worked on developing feminist theories and methodologies on intersectional gender, feminist politics, and multiple forms of violence. Recent publications are "From Gender Regimes to Violence Regimes" (Social Politics, 2020, with Hearn, Humbert, Balkmar, and Delaunay), "The Multiple Meanings of FGM: A Feminist Violence Studies Analysis" (Sociological Research/Sociologisk Forskning, 2020) and "Violence as a System: Violence, Masculinity and Change" (Journal of Social Medicine/Socialmedicinsk tidsskrift, 2020, with Meier-Arendt). 